NOTE

\title{
Interactions between Bovine Plasma Albumin and Sodium Dodecyl Sulfate Studied by Means of CD Spectra
}

\author{
Yoshio InOUe, Shigeru SASE, Riichiro CHÛJô, \\ Shunji NAGAOKA, ${ }^{*}$ and Masaru SOGAMI* \\ Department of Polymer Chemistry, Tokyo Institute of Technology, \\ O-okayama, Meguro-ku, Tokyo 152, Japan. \\ *Department of Physiology, School of Medicine, Gifu University, \\ Gifu 500, Japan.
}

(Received August 30, 1979)

KEY WORDS Albumin / Surfactant / Circular Dichroism / Protein /

The binding of anionic surfactant, sodium dodecyl sulfate $\left(\mathrm{NaDodSO}_{4}\right)$, to the protein, bovine plasma albumin, has been studied extensively over the last two decades. ${ }^{1-6}$ The binding isotherm has been explained ${ }^{1,3-6}$ in terms of equilibria between the following protein (A)- $\mathrm{NaDodSO}_{4}$ (D) complexes:

$$
\mathrm{A} \rightleftarrows \mathrm{AD}_{\mathrm{m}} \rightleftarrows \mathrm{AD}_{n} \rightleftarrows \mathrm{AD}_{2 n} \rightleftarrows \mathrm{AD}_{>2 n}
$$

where $m \simeq 10$ and $n \simeq 40$. The native albumin has $m$ high-affinity sites for $\mathrm{NaDodSO}_{4}$ binding. The occupation of these $m$ sites by $\mathrm{NaDodSO}_{4}$ results in a conformational change in the albumin molecule, followed by an exposure of $n$ sites and the destruction of the initial $m$ sites. When these $n$ sites are coupled with $\mathrm{NaDodSO}_{4}$, a further conformational change occurs in the protein molecule followed by an exposure of $2 n$ sites and the destruction of the $n$ sites. With further bindings at $\mathrm{AD}_{>2 n}$, the protein molecule becomes denatured. ${ }^{4}$

The free energy of the binding of $\mathrm{NaDodSO}_{4}$ to the protein consists of two main terms: electrostatic and hydrophobic interactions. In a preceding paper, ${ }^{7}$ the interactions between bovine plasma albumin and $\mathrm{NaDodSO}_{4}$ were studied by ${ }^{13} \mathrm{C}-\mathrm{NMR}$ spectra. It was found that in the region of the initial binding of the surfactant to the high-affinity sites on the protein, both the surfactant polar head group and alkyl chain interacted with the protein. With an excess of highaffinity sites, surfactant molecules are in a micellelike environment in which the surfactant's alkyl chains are associated with the nonpolar groups of the protein.
It is well known that a variety of proteins forms complexes with surfactant $t^{8-10}$ and that the interaction of anionic surfactant and cationic polypeptides is strong, ${ }^{11,12}$ but the structure of the protein nonpolar region in the protein-surfactant complex is not yet clear. In this paper, the interactions between bovine plasma albumin and $\mathrm{NaDodSO}_{4}$ will be studied by observing circular dichroism (CD) spectra, with special attention given to the protein's side chain aromatic bands.

\section{EXPERIMENTAL}

Crystallized bovine plasma albumin was purchased from Armour Pharmaceutical Co. and was defatted by the modified Chen methods. ${ }^{13,14}$ $\mathrm{NaDodSO}_{4}$ was purchased from Nakarai Chemicals Ltd., Kyoto, and was recrystallized twice from methanol solution. The CD specta of $0.19 \%$ albumin solutions at $25^{\circ} \mathrm{C}$ were measured with a JASCO J$40 \mathrm{~S}$ spectrometer. CD strength is expressed in terms of mean residue ellipticity $[\theta]$ in degree $\cdot \mathrm{cm}^{2} \mathrm{dmol}^{-1}$, where the value of 118 was used as the mean amino acid molecular weight per residue for bovine plasma albumin. The $\mathrm{pH}$ values of both the albumin and $\mathrm{NaDodSO}_{4}$ stock solutions were adjusted to 5.4.

\section{RESULTS AND DISCUSSION}

The circular dichroism spectra in the peptide bond region $(200-260 \mathrm{~nm})$ for the protein in the absence and the presence of $\mathrm{NaDodSO}_{4}$ are in reasonable 
agreement with results previously reported for albumin. ${ }^{10}$ By comparing the experimental CD strength at $220 \mathrm{~nm},[\theta]_{220}$, with typical values of $[\theta]_{220}$ for the $\alpha$-helical, $\beta$-sheet, and random-coil forms of polypeptides, ${ }^{15}$ it was estimated that the protein, even when $\mathrm{NaDodSO}_{4}$ is present up to a molar ratio $\left[\mathrm{NaDodSO}_{4}\right] /[$ albumin $]=150$, has a nearly constant helicity as high as $50 \%$. This result is consistent with that obtained from ${ }^{13} \mathrm{C}-\mathrm{NMR},{ }^{7}$ $\mathrm{ESR},{ }^{16}$ and ${ }^{1} \mathrm{H}-\mathrm{NMR},{ }^{2}$ so that the denaturation effect of $\mathrm{NaDodSO}_{4}$ is small and much of the secondary and tertiary structure remains intact even after, denaturation by the binding of many surfactant molecules.

Figure 1 shows the CD spectra in the aromatic dichroic band of the protein complexed with various amounts of $\mathrm{NaDodSO}_{4}$. The chromophores contributing to this region of the spectrum may be nineteen tyrosine, two tryptophan, and twentysix phenylalanine residues and seventeen disulfide bonds. These numbers are based on the bovine plasma albumin

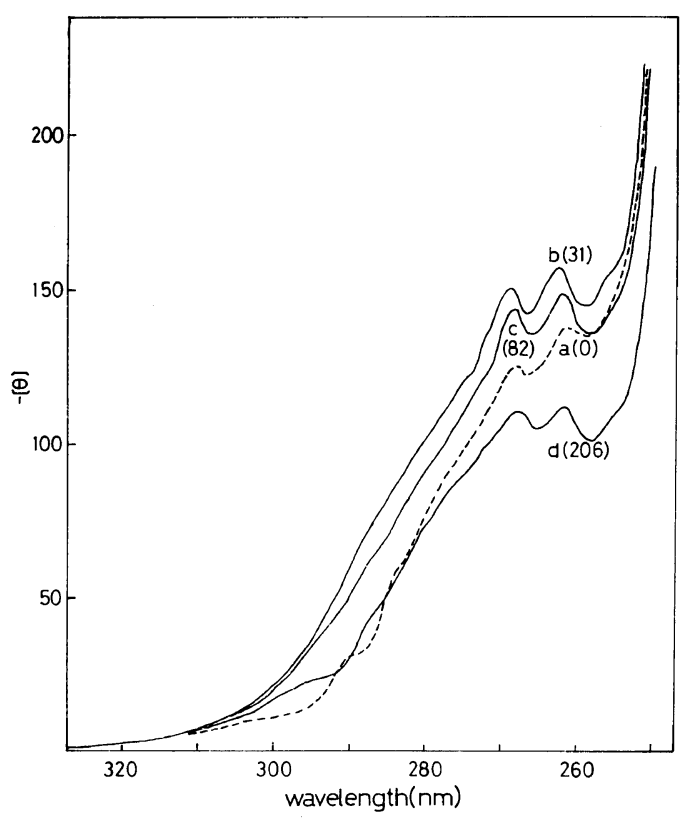

Figure 1. $\mathrm{CD}$ spectra in the aromatic region of bovine plasma albumin complexed with various amounts of sodium dodecyl sulfate $\left(\mathrm{NaDodSO}_{4}\right)$. The number in the brackets on each spectrum is the molar ratio $\left[\mathrm{NaDodSO}_{4}\right] /[$ albumin] at $0.19 \%$ bovine plasma albumin in ${ }^{2} \mathrm{H}_{2} \mathrm{O} ; \mathrm{pH}, 5.4-6.8 ; 25^{\circ} \mathrm{C}$. molecule. ${ }^{17} \mathrm{~A}$ curve a of this figure represents the $\mathrm{CD}$ spectrum of the native protein without $\mathrm{NaDodSO}_{4}$ binding. The tail of the spectrum at $\geqq 310 \mathrm{~nm}$ could be assigned to the disulfide bond. Indeed, this band was extinguished when the disulfide bond was destructed by the addition of dithiothreitol. ${ }^{18}$ Such a tail could not be observed in the spectrum of the protein containing no disulfide bonds. ${ }^{19}$

The shoulder at $290 \mathrm{~nm}$ could be a tryptophan band. ${ }^{19}$ This band is extinguished in curve $b$ which represents the spectrum of the $\mathrm{NaDodSO}_{4}$-protein complex at a molar ratio of added $\mathrm{NaDodSO}_{4}$ to albumin, $\left[\mathrm{NaDodSO}_{4}\right] /[$ albumin $]=31$. This implies the occurence of considerable change in the environment of the tryptophan residues (two tryptophan residues are included in each albumin molecule ${ }^{17}$ ). Therefore, it is thought that some of the high affinity sites for $\mathrm{NaDodSO}_{4}$ coincide with or are very close to the positions of the tryptophan residues in the native protein. This supports the finding that both the two tryptophan residues in albumin are exposed to the solvent in the native state without $\mathrm{NaDodSO}_{4}$ binding ${ }^{20,21}$ and that they are shielded from the solvent by $\mathrm{NaDodSO}_{4}$ binding. ${ }^{22-24}$

Since the $N$-acetyl-L-phenylalanine in aqueous solution shows two weak negative bands in the region of $260-270 \mathrm{~nm},{ }^{25}$ two similar negative bands appearing in curve a are likely to be assigned to the phenylalanine residues coalesced with negative bands due to other chromophores. The CD curve of the L-tyrosine residue displays a negative peak at about $275 \mathrm{~nm}$ at acidic $\mathrm{pH}$, and this peak shifts to a longer wavelength in going from $\mathrm{pH} 4.8$ to $12.0 .^{26,27}$ Cystine derivatives also show a single and broad negative $C D$ band without fine structure at about $260 \mathrm{~nm} .{ }^{25}$ Two negative bands appearing in the region of $260-270 \mathrm{~nm}$ come to exist after destruction of the disulfide bond by the addition of dithiothreitol. Thus the assignment of these two bands to phenylalanine residues may be reasonable.

These two bands continually exist following the complex formation with $\mathrm{NaDodSO}_{4}$ as shown in the curves b, c, and d ([NaDodSO $\left.{ }_{4}\right] /[$ albumin $]=31,80$, and 206, respectively). Figure $2 \mathrm{~A}$ shows the positions in the wavelength of these two $\mathrm{CD}$ bands as a function of the molar ratio. Both bands change their positions in a manner similar to each other. With an increase in the complex formation of the protein with $\mathrm{NaDodSO}_{4}$, the red shift is observed followed by stepwise blue shifts. According to the primary struc- 


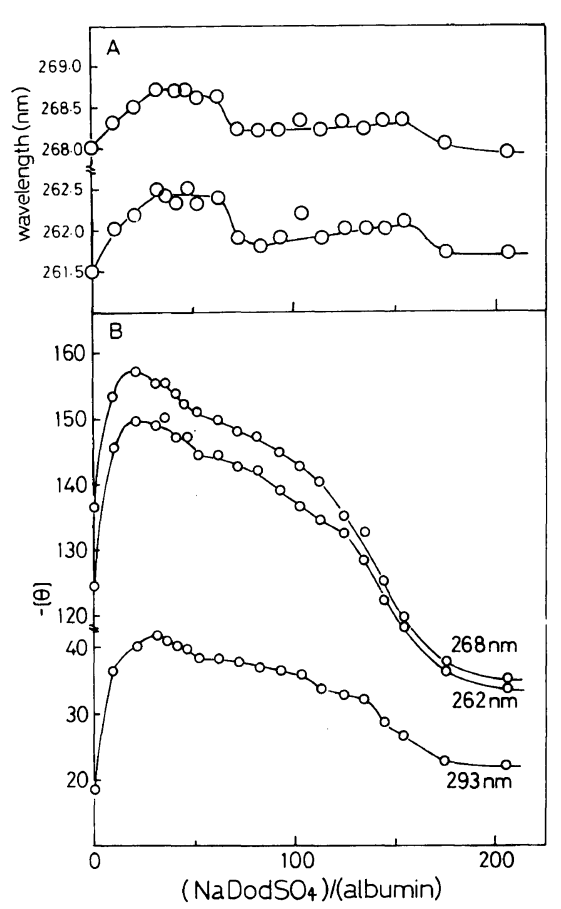

Figure 2. Variations in (A) the positions in wavelength of two CD bands ( $\sim 262$ and $\sim 268 \mathrm{~nm}$ ), and (B) the CD strengths at various wavelengths, as a function of molar ratio $\left[\mathrm{NaDodSO}_{4}\right] /[$ albumin], at a constant concentration of bovine plasma albumin $(0.19 \%) ; \mathrm{pH}, 5.4-6.8 ; 25^{\circ} \mathrm{C}$.

ture of albumin, ${ }^{17}$ which contains two tryptophan residues, the protein contains twentysix phenylalanine residues in a molecule and a phenylalanine residue is adjacent to one of the tryptophan residues. Since the two tryptophan residues in the native states are considered to be exposed to the solvent, ${ }^{20,21}$ some of phenylalanine residues are also expected to be exposed to the solvent in the native state without $\mathrm{NaDodSO}_{4}$ binding. These initially exposed phenylalanine residues become shielded from the solvent through the hydrophobic interaction with the hydrocarbon tail of $\mathrm{NaDodSO}_{4}$ and this shielding may bring about the intial red shift.

The following blue shifts may result from the conformational changes in the protein brought about by the binding of many $\mathrm{NaDodSO}_{4}$ molecules and cause changes in the environment of some of the buried phenylalanine residues, i.e., some buried ones become exposed to the solvent and take on a hydrophilic environment. In a previous report,${ }^{23}$ the bands due to tyrosine and phenylalanine residues in the ultraviolet difference spectra of bovine serum albumin, produced by binding dodecyl sulfate and sulfonate, show the red shifts as the result of binding with a few equivalences of the surfactant. Also, in that report, a discription is given of the reversal of the red shift to the blue shift when $4-6$ equivalences of surfactant are bound. This reversion is attributable to the local disorganization of the protein.

Figure 2B shows the $-[\theta]$ values at 262,268 , and $293 \mathrm{~nm}$ as a function of the molar ratio [NaDodSO 4$] /[$ albumin]. The wavelength of $293 \mathrm{~nm}$ was chosen as a representative which may be only slightly influenced if at all by a large negative band of peptide bond region $(200-260 \mathrm{~nm})$. The behavior of these three curves resembles each other: the $-[\theta]$ values abruptly increase at first, then decrease stepwise. The initial increase may reflect an increase in the rigidity of the protein with the binding of $\mathrm{NaDodSO}_{4}$ to the high affinity sites resulting in an increase in the asymmetry of the environment of the chromophores, because of the decrease in the interaction of solvent with the protein. The abrupt decrease at molar ratios $\left[\mathrm{NaDodSO}_{4}\right] /$ [albumin] $>110$ reflects an unfolding of the protein brought about by large amounts of $\mathrm{NaDodSO}_{4}$ bindings.

The curves in Figures 2A and 2B can be divided into several regions based on the changing behavior of each curve. This suggests that the stepwise complex formations between the protein and $\mathrm{NaDodSO}_{4}$ is accompanied by the stepwise conformational changes in the protein. The curves probably reflect the complex formation process found electrophoretically $^{2,8}$ of

$$
\mathrm{A} \rightarrow \mathrm{AD}_{\mathrm{m}} \rightarrow \mathrm{AD}_{n} \rightarrow \mathrm{AD}_{2 n} \rightarrow \mathrm{AD}_{>2 n}
$$

where $m \simeq 10$ and $n \simeq 40$.

It is interesting to note that the CD bands of the side chain aromatic region show the conformational change by the binding of much $\mathrm{NaDodSO}_{4}$, while the helicity as a whole protein molecule estimated from the peptide bond region is nearly constant, being about $50 \%$ over the range of molar ratio $\left[\mathrm{NaDodSO}_{4}\right] /[$ albumin $]=0-150$. This seeming inconsistency is qualitatively explainable by a model which assumes that basic amino acid residues such as arginine, histidine, and lysine have an enhanced ability to propagate the ordered segment structure in 
the presence of anionic surfactant, ${ }^{10-12}$ whereas the nonpolar region of the protein changes its conformation more or less by the hydrophobic interaction with the alkyl chain of the surfactant. ${ }^{7}$ To give a quantitative explanation, a detailed examination based on the primary structure of the protein is required.

\section{REFERENCES}

1. J. Steinhardt and J. A. Reynolds, "Multiple Equilibria in Protein," Academic Press, New York, N.Y., 1969.

2. J. Oakes, J. Chem. Soc. Faraday Trans. 1, 70, 2200 (1974).

3. R. V. Decker and J. F. Foster, Biochemistry, 5, 1242 (1966).

4. A. Ray, J. A. Reynolds, H. Polet, and J. Steinhardt, Biochemistry, 5, 2606 (1966).

5. J. A. Reynolds, S. Herbert, H. Polet, and J. Steinhardt, Biochemistry, 6, 937 (1967).

6. J. A. Reynolds, J. P. Gallacher, and J. Steinhardt, Biochemistry, 9, 1232 (1970).

7. Y. Inoue, S. Sase, R. Chûjô, S. Nagaoka, and M. Sogami, Biopolymers, 18, 373 (1979).

8. R. Pitt-Rivers and F. S. A. Impiombato, Biochem. J., 109, 825 (1968).

9. J. A. Reynolds and C. Tanford, J. Biol. Chem., 245, 5161 (1970).

10. W. L. Mattice, J. M. Riser, and D. S. Clark, Biochemistry, 15, 4264 (1976).
11. R. W. McCord, E. W. Blakeney, and W. L. Mattice, Biopolymers, 16, 1319 (1977).

12. I. Satake and J. T. Yang, Biopolymers, 14, 1841 (1975).

13. R. F. Chen, J. Biol. Chem., 242, 173 (1967).

14. M. Sogami, J. F. Foster, Biochemistry, 7, 2172 (1968).

15. N. Greenfield and G. D. Fasman, Biochemistry, 8, 4108 (1969).

16. J. Oakes and M. C. Cafe, Eur. J. Biochem., 36, 559 (1973).

17. J. R. Brown, Federation Proc., 35, 2142 (1976).

18. W. L. Zahler and W. W. Cleland, J. Biol. Chem., 243, 716 (1968).

19. B. Jirgensons, Biochim. Biophys. Acta, 434, 58 (1976).

20. T. T. Herskovites and Sr. M. Sorensen, Biochemistry, 7, 2533 (1968).

21. M. Sogami and S. Ogura, J. Biochem., 323 (1973).

22. J. Steinhardt, J. Krijn, and J. G. Leidy, Biochemistry, 10, 4005 (1971).

23. J. Steinhardt, J. G. Leidig, and J. P. Mooney, Biochemistry, 11, 1809 (1972).

24. M. Sogami, M. Ueda, and S. Ogura, Biochim. Biophys. Acta, 310, 487 (1973).

25. M. Shiraki, Sci. Par. Collect. General Educ. Univ. Tokyo, 19, 151 (1969).

26. W. B. Gratzer and G. H. Beaven, Biopolymers, 11, 689 (1972).

27. R. Mayer, P. Gauduchon, G. Spach, and $\mathrm{Ph}$. Wahl, Biopolymers, 17, 337 (1978).

28. F. W. Puttnam and H. Neurath, J. Biol. Chem., 159, 195 (1945). 